University of Louisville

ThinkIR: The University of Louisville's Institutional Repository

Electronic Theses and Dissertations

$1-1929$

\title{
Hydrogen ion concentration in lead acetate solutions.
}

Emile Pragoff 1907-1991

University of Louisville

Follow this and additional works at: https://ir.library.louisville.edu/etd

\section{Recommended Citation}

Pragoff, Emile 1907-1991, "Hydrogen ion concentration in lead acetate solutions." (1929). Electronic Theses and Dissertations. Paper 1150.

https://doi.org/10.18297/etd/1150

This Master's Thesis is brought to you for free and open access by ThinkIR: The University of Louisville's Institutional Repository. It has been accepted for inclusion in Electronic Theses and Dissertations by an authorized administrator of ThinkIR: The University of Louisville's Institutional Repository. This title appears here courtesy of the author, who has retained all other copyrights. For more information, please contact thinkir@louisville.edu. 
UNIVERSITY OF LOUISVILLE

"HYDROGEN ION CONGENTRATION

IN LEAD ACETATE SOLUTIONS" .

A Dissertation

Submitted to the Faculty

of the Graduate school of the College of Liberal Arts

In Partial Fulfiliment of the

Requirements for the Degree

of Master of Sclence

Department of Chemistry

by

Emile Pragoff, Jr.

1929 
TABLE OF CONTENTS

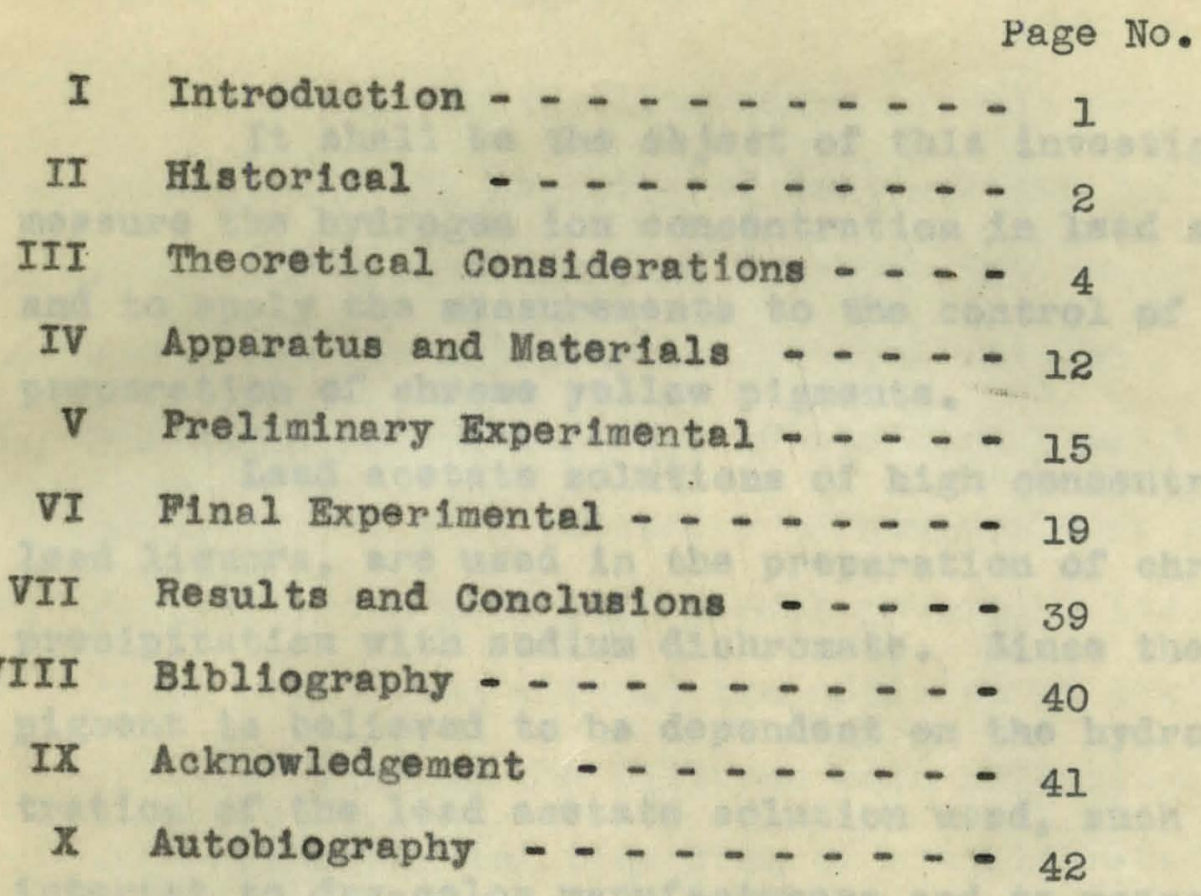




\section{INTRODUCTORY.}

It shall be the object of this investigation to measure the hydrogen ion concentration in lead acetate solutions and to apply the messurements to the control of color in the preparation of chrome yellow plgments.

Lead acetate solutions of hlgh concentration, known as lead 11quors, are used in the preparation of chrome yellows by preclpitation with sodium dichromate. Since the color of the plgment is belleved to be dependent on the hydrogen 1on concentration of the lead acetate solution used, such a study is of Interest to dry-color manufacturers and to users of chrome yellows.

The methods now in use for the analysis of lead acetate are to be reviewed, and an attempt will be made to measure the hydrogen ion concentration of the lead acetate solutions by a potentiometric method.

It is proposed, therefore, to measure the hydrogen ion concentration in the lead acetate solutions, and to show the effect of hydrogen ion concentration on the color of chrome yellow pigments. 
HISTORICAL

A review of the literature reveals several methods for determining the basielty of lead acetate solutions, but no method for determining the hydrogen fon concentration. The methods given are volumetric. Several follow:

1. Preolpitation with excess of standard oxalic acid and bactitration w1th potassium permanganate or alkal1. (1)

2. Precipitation with half-normal potassium lodate solution, flrst with, then without the addition of acetic acid; decomposition of the filtrate with potassium lodide and sulfuric acid, and titration of the liberated lodine with tenth-normal sodium thiosulfate solution. (2)

3. Precipitation with tenth-normal potassium chromate in the same manner as above.

4. Addition of excess acid, then sodium sulfate, filtration, and titration of the acid against phenolphthalein.

5. Mitration directly with normal acetic acid using methyl red as Indicator.

of these methods, numbers one and four appear to give only a messure of the total lead present. Methods two and three both depend upon the difference in the amount of lead precip1 tated with and without the presence of acetic acid. The chromate method is said to be the best and is given in deta1l as follows: 
Half a gram of lead acetate is mixed with 5 c.c. of dilute acetic acid and $150 \mathrm{c.c}$. of tenth-normal potassium chromate solution; the mixture is shaken and diluted to $250 \mathrm{c} . \mathrm{c}$. . It is then filtered and a 50 c.c. portion of the filtrate is treated with 3 grams of potassium lodide and $10 \mathrm{c.c}$. of dilute sulfuric acid. The liberated lodine is titrated w1th tenth-nornal sodium thiosulfate solution. A second titration is made without the addition of acetic acid. The equations for the two reactions are: (a) for total lead.

$$
\begin{gathered}
2\left(\mathrm{CH}_{3} \mathrm{COO}_{2} \mathrm{~Pb} \cdot \mathrm{Pb}(\mathrm{OH})_{2}+3 \mathrm{~K}_{2} \mathrm{CrO}_{4}+2 \mathrm{CH}_{3} \mathrm{COOH}\right. \\
\longrightarrow 3 \mathrm{PbCrO}_{4}+6 \mathrm{CH}_{3} \mathrm{COOK}+2 \mathrm{H}_{2} \mathrm{O}
\end{gathered}
$$

(b) for lead present as neutral lead acetate. $2\left(\mathrm{CH}_{3} \mathrm{COO}\right)_{2} \mathrm{~Pb} \cdot \mathrm{Pb}(\mathrm{OH})_{2}+2 \mathrm{~K}_{2} \mathrm{CrO}_{4}$

$$
\rightarrow 2 \mathrm{PbCrO} \mathrm{Pb}_{4} \cdot \mathrm{Pb}(\mathrm{OH})_{2}+4 \mathrm{CH}_{3} \mathrm{COOK}
$$

A method in use industrially in some dry color plants is as follows:

A known weight of lead acetate solution, whose specific gravity has been determined, is diluted to 500 c.c. with hot water and kept hot during titration with concentrated hydrochloric ac1d. The end-point is reached when a drop taken out no longer gives a precipitate with a solution of mercuric chloride. The strength of the hydrochloric acid used is calculated from 1ts specif1c gravity measured by a hydrometer. This method is not of great accuracy and gives only a measure of the total lead present.

None of these methods gives gny measure of the hydrogen Ion concentration of the lead acetate solution. 


\section{THFORY}

When a metal is immersed in s solution of its ions potential difference is established between the metal and the solution. This difference of potential is known as the electrode potential of the metal and is represented by the Nernst equation.

$$
E=\frac{R T}{n F} \log \frac{p}{p} \quad \text { (1) }
$$

I 1 is the difference of potential between metal and solution If is the gas constant ( 8.32 joules per degree)

T is the absolute temperature

$n$ is the valence of the ion

$F$ is the Faraday constant ( 96.500 coulombs)

P 18 the solution pressure of the metal

p is the osmotic pressure of the solution

The osmotic pressure $p$ is a function of the concentration, so $\mathrm{p}$ is proportional to $\mathrm{c}$. Since the solution pressure $P$ is a function of the metal only, $\frac{R T}{n F} \log K p$ is a constant, dependent only on the metal and is equal to Bo, where Eo is the electrolytic or normal electrode potent1al. Then equation (1) becomes

$$
\begin{aligned}
& E=E_{0}+\frac{R T}{n F} \log \frac{1}{p} \\
& E=E_{0}+\frac{R T}{n F} \log \frac{1}{C}
\end{aligned}
$$


When the concentration of the lons is normal $C$ becomes unity, then $\frac{R T}{h F} \log \frac{1}{C}$. becomes equal to zero and $E=E$. A gas electrode can be substituted for the metal electrode, In which case an equilibrium exists between the gas and its lons. Such an electrode is the hydrogen electrode In which the equilibrium is represented by

$$
\mathrm{H}_{2} \rightleftarrows 2 \mathrm{H}^{+}
$$

A hydrogen electrode is formed by partially immersing in a solution contalning hydrogen lons a strip of platinum which is coated with platinum black. Hydrogen gas is then bubbled over the platimum and through the solution and at equilibrium a potential difference exists between the molecular hydrogen and the hydrogen 1ons.

The equation giving the relation between hydrogen ion concentration and the potential of the electrode is

$$
E=E_{0}+\frac{R T}{n F} \log \frac{1}{C_{H^{+}}}
$$

where

$\mathrm{F}$ is the single potential corresponding to lonic concentration $\mathrm{C}$ Eo is the normal electrode potential

$C$ is the hydrogen ion concentration of the electrolyte The other terms have their usual signifleance

In the case of hydrogen at $25^{\circ} \mathrm{C}$ and at one atmosphere pressure, this equation becomes

$$
E=.246+.0591 \log _{10} \frac{1}{C_{H^{+}}}
$$

where .246 is

the potential of the hydrogen electrode referred to the saturated ealomel electrode as zero. 
denerally the hydrogen ion concentration is expressed in terms of the numerical value of $\log \frac{1}{C_{H^{+}}}+$This is called, at the suggestion of sorensen (6) and Clark, the $\mathrm{Ph}$ of the solution, or the hydrogen ion exponent, and bears the following relationship:

$$
p H=\log \frac{1}{C_{H^{+}}} \text {or } C_{H^{+}}=1 \times 10^{-p H}
$$

An electromot1ze force results when a hydrogen electrode is combined with a standard reference electrode. The electromotive force is the result of potential differences at: (1), (2) the metal-solution functions

(3) the solution-solution function

(4) the metal-metal junction

If the temperature is constant (4) is negligible, and generally (3) is exceedingly small; consequently the electromotive force of the cell may be considered to be due to the differences of potential arising at the two electrodes.

For reference electrode the saturated calomel electrode may, be used, in which case, the electromotive force is given by $\mathrm{E}=\mathrm{E}_{1}+\mathbb{E}_{2} \quad$, where $\mathrm{E}$, is the single potential of the hydrogen electrode and $\mathrm{E}_{2}$ is the potential of the reference electrode. Such a cell may be represented by, in the case of the hydrogen electrode,

(Pt) $\mathrm{H}_{2} / \mathrm{H}^{+}$/Saturated $\mathrm{Hg}_{2} \mathrm{Cl}_{2}$ in saturated $\mathrm{KCl} / \mathrm{Hg}_{2} \mathrm{Cl}_{2}+\mathrm{Hg}$ where the saturated calomel electrode has the following value between 5 degrees and 60 degrees Centigrade, $E_{2}=.5266+.0002\left(t_{c}-25\right)$ volts. 
To measure the electromotive force set up between two electrodes 1 , a cell, use is made of the Poggendorf compensation method using a potentiometer indicator.

Instead of the hydrogen electrode the quinhydrone electrode of Bi1lman (7) may be used for measuring hydrogen Ion concentration. Quinhydrone is an adition product which is a mixture of one part of quinone and one part of hydroquinone. A saturated water solution is only .005 molar. The condition of equilibrium in such a solution is represented as follows:<smiles></smiles>

When a platinum or gold electrode is dipped into a saturated solution of quinhydrone a difference of potential is established. The quinhydrone electrode can be used for hydrogen ion concentration determinations in ac1d solutions, but does not function well in alkaline solutions over a $\mathrm{Ph}$ of 9 , because of the action of alkalies on quinhydrone.

When combined with a saturated calomel electrode, the equation connecting 1 ts electrode potential with the hydrogen ion concentration is

$$
E=.0591 \log _{10} \frac{1}{C_{H^{+}}}-.452
$$

at $25^{\circ} \mathrm{C}$, where

.4521 sthe potential of the saturated quinhydrone electrode compared to the saturated calomel electrode as zero. Neutralization reactions involve the combination of hydrogen and hydroxyl lons to form slightly lonized water.

$$
\mathrm{H}^{+}+\mathrm{OH}^{-} \rightleftarrows \mathrm{H}_{2} \mathrm{O}
$$


By applying the mass action law the concentration of hydrogen and hydroxyl Ions may be deduced from the above equation.

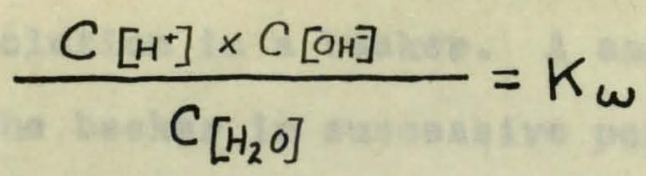

where the brackets denote the concentration of the respective Ions and $\mathrm{Kw}$ is known as the 1onization constant of water. since the concentration of non-1onized water in solutions is more or less constant, the equation becomes

$$
C\left[\mathrm{H}^{+}\right] \times C\left[\mathrm{OH}^{-}\right]=\mathrm{K}_{\omega}
$$

The values of $\mathrm{Kw}$ vary with the temperature, increasing sharply as shown in the following table:

$\begin{array}{cccc}\text { TEMPERATURE: } & \mathrm{Kw} & \frac{\mathrm{pH}}{12} & 14.93 \\ 0^{\circ} \mathrm{C} . & .12 \times 10^{-14} & 14.23 \\ 18^{\circ} \mathrm{C} . & 1.04 \times 10^{-14} & 13.98 \\ 25^{\circ} \mathrm{C} . & 5.66 \times 10^{-14} & 13.25 \\ 50^{\circ} \mathrm{C} . & 58.2 \times 10^{-14} & 12.25 \\ 100^{\circ} \mathrm{C} . & 10 \times 14 & \end{array}$

at room temperature $\mathrm{Kw}$ is very nearly $1 \times 10^{-14}$. Therefore, in pure water

$$
C_{H^{+}}=C_{O H^{-}}=\sqrt{K_{\omega}}=\sqrt{1 \times 10^{-14}}=1 \times 10^{-7}
$$

or the concentration of hydrogen and of the hydroxyl ions is $1 \times 10^{-7}$.

The neutralization of acids and bases is accompanied by changes in the concentration of hydrogen and hydroxyl 1ons. These changes can be measured by the use of a hydrogen electrode The flrst application of such work was by Böttgex, (9), who showed this method to be satisfactory. 
In carrying out such titration the hydrogen electrode and the side arm of a saturated calomel electrode are immersed In the acid solution in a beaker. A solution of standard alkali is run into the beaker in successive portions from a burette. After the addition of each portion, the electromotive force of the cell is measured and the potentiometer readings are plotted agalnst the corresponding burette readings. The amount of alkall required to neutralize the acid is determined from the graph by the number of cubic centimeters of alkall which correspond to the voltage which is equivaleht to a $\mathrm{pH}$ of 7 .

The results of titrations of hydrochloric acid and acetic acld with sodium hydroxide are shown in the curves, where the abscissae represent the number of cub1c centimeters of sodium hydroxide added to the solution from a burette, and the ordinates represent the corresponding values of $\mathrm{pH}$. It is seen that, in both cases, a sharp break occurs when the endpoint of the titration is reached. Acetic acid shows an initial electromotive force grester than hydrochloric acid, since the hydrogen ion concentration is much less. As the neutral point is neared greater changes in the hydrogen ion concentration occur with the addition of small quantities of base and when the neutral point is reached the curve shows a sharp break. The middle point of the curve corresponds to the normal salt, when both acid and base are present in equal amounts. Since a neutral solution has a pH of 7 , the voltage of the electrode should be $\mathrm{E}=\mathrm{E} 0+.0591 \mathrm{pH}$ $B=.246+.0591 \times 7$

$F=.6597$ volts when measured against a

saturated calomel electrode. 
Titration of hydrochloric and acetic acids by sodium hydroxide.

13

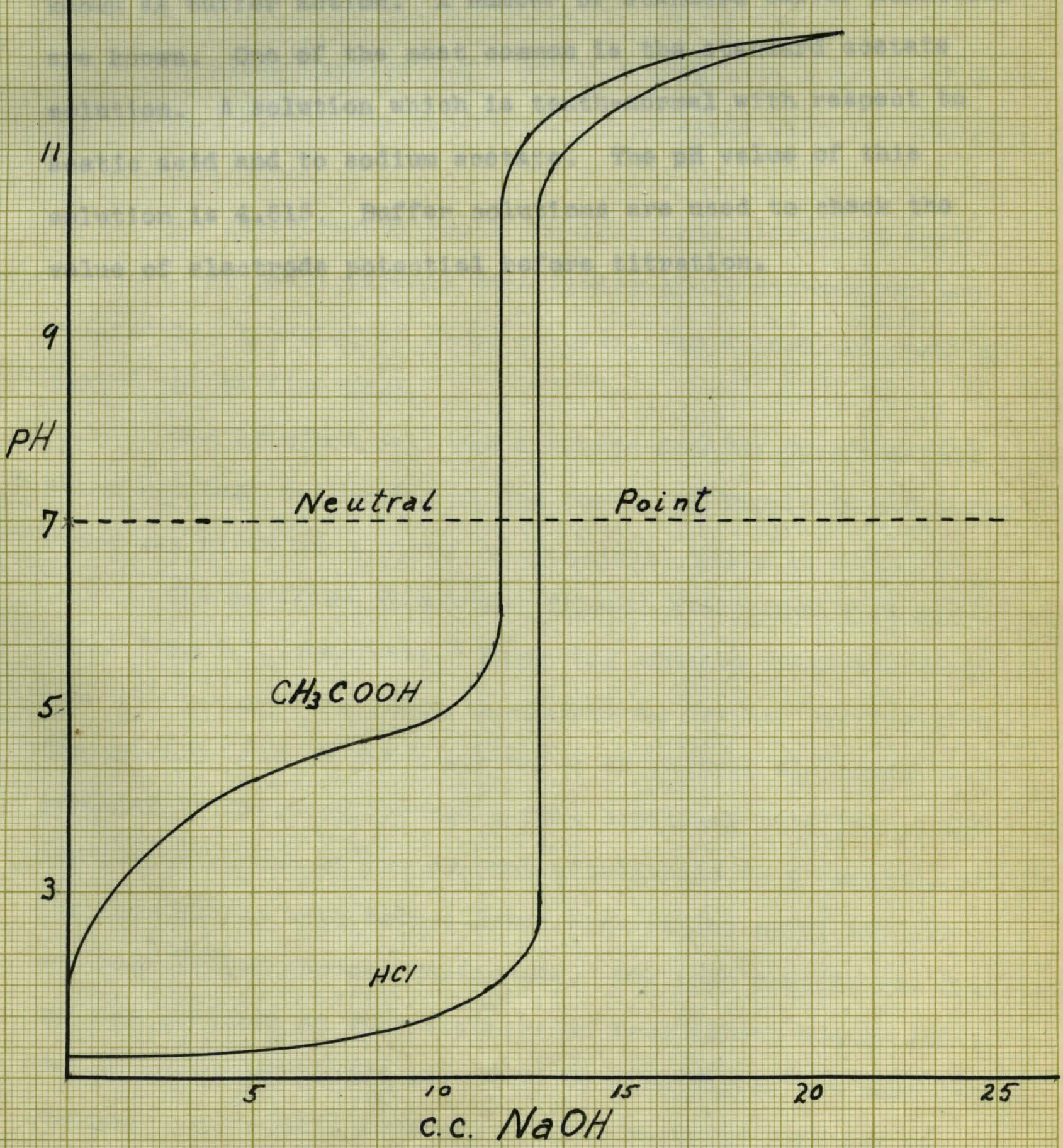


Solutions of a weak acid and one of its salts or a weak base w1th one of 1ts salts possess the property of maintaining stable hydrogen ion concentration, which is but little affected by additions of acld or alkall, or by dilution. This resistance to changes in hydrogen ion concentration is known as buffer action. A number of standard buffer solutions are known. One of the most common is the standard acetate solution. A solution which is tenth-normal with respect to acetlc acld and to sodium acetate. The $\mathrm{pH}$ value of this solution is 4.615. Buffer solutions are used to check the value of electrode potential before titration. 


\section{APPARATUS AND MATERIALS}

The apparatus used for measuring the hydrogen ion concentration was that contained in the potentiometer clreuit, as shown in the diagram. Leeds and Northrup instruments were tsed throughout.

The potentiometer was a student type with a range of 0 to 1.6 volts. With a two hundred division slide wire its accuracy was. 5 m11l1volts.

The galvanometer was a portable type d'Arsonval w1th pointer. It had a current sensitivity of .5 microampere per m1llimeter, a period of three seconds, and a critical damping resistance of 2400 ohms.

The standard cell was a Weston Gadmlum Standard Cell which had been ealibrated by the Bureau of Standards and whose value was given as 1.01878 International Volts at $22^{\circ} \mathrm{C}$.

The modified Hildebrand calomel electrodes were prepared from C.P. chemicals. Baker and Adamson chemlcals were used since they were found to require no further purification. The mercury used in the preparation of calomel electrodes was purlfled by dropping through a fine caplilary tube into a 100 centimeter column of ten percent nitrie acid in a burette. It was then washed with water, dried with filter paper and for one hour at 110 degrees Centigrade. The lead acetate was Baker's and was purifled by recrystalization from dilute acetic acid. The potassium hydroxide was C. P. by alcohol and was pure enough for use. The acetic acid was Baker's Analyzed C.P. and was $99.5 \%$ pure acetic ac1d. 
The quinhydrone was prepared by the addition of an equivalent weight of ferric chloride to a solution of hydroquinone It was re-crystalized from water and was found to be free from Iron.

Conductivity water was prepared as needed by successive distillation over potassium dichromate and barlum hydroxide, the receiver being a paraffin-lined bottle. The entrance of carbon doxide into the apparatus was prevented by the use of soda 11 me tubes. 


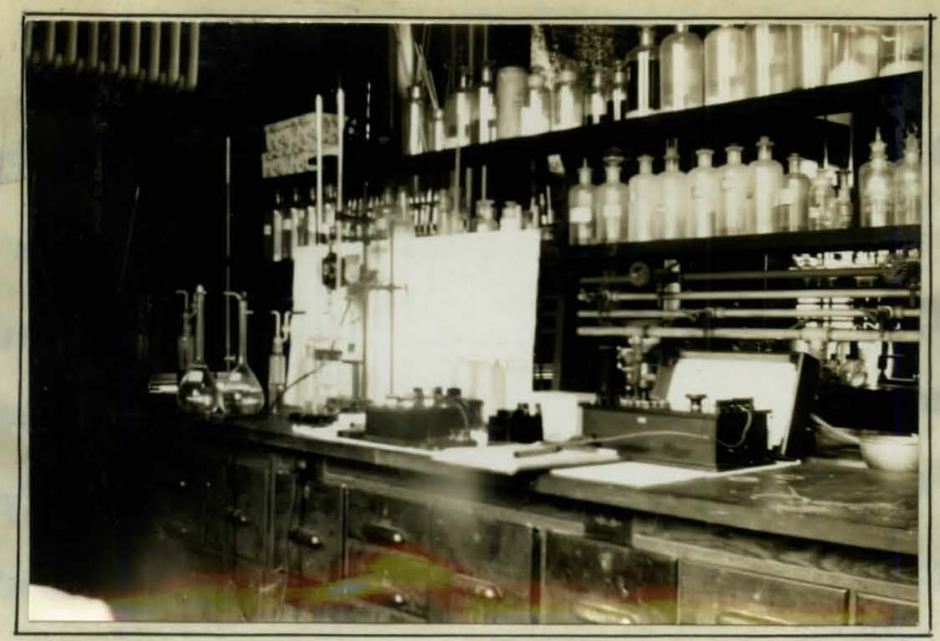

DIAGRAM OF APPARATUS

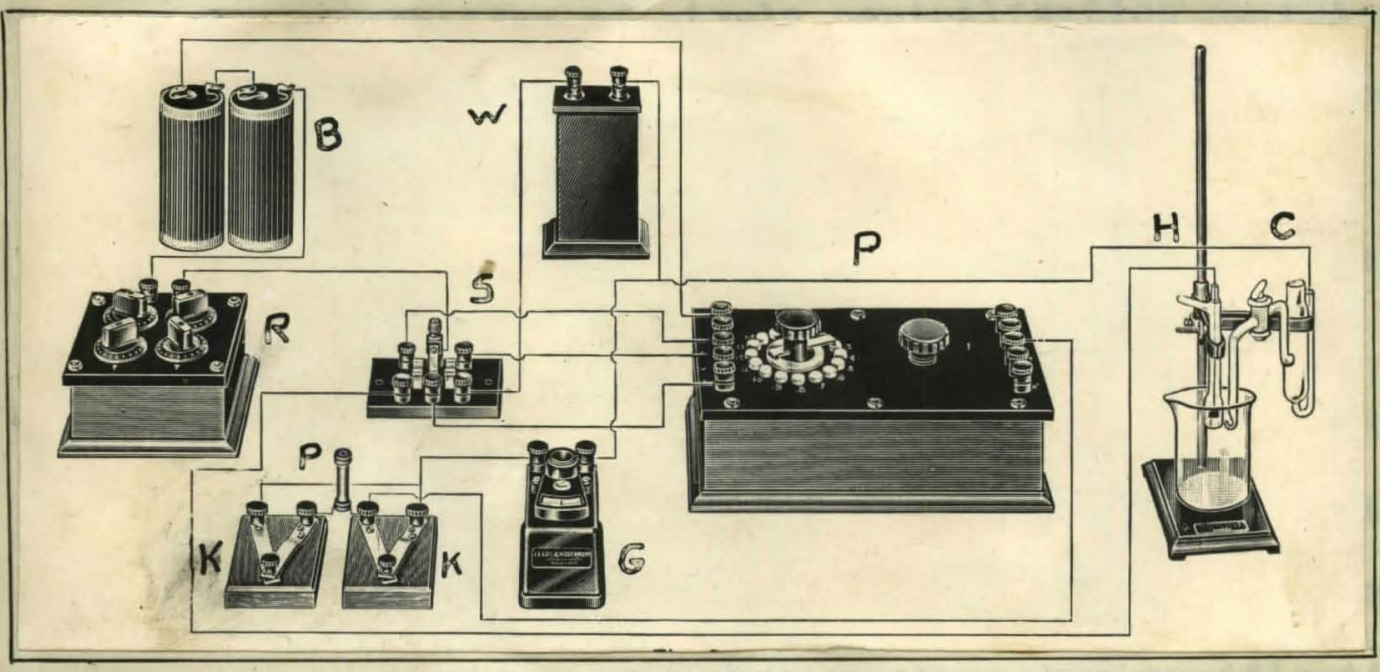

P- Student Potentiometer

G- Galvanometer

W- Weston Standard Cell

R-Resistance (1 to 1000 ohms)

$\mathrm{K}, \mathrm{K}$ - Tapping Keys

C- Calomel Electrode

H- Hydrogen Electrode

P- Protective Resistance (10,000 ohms)

S- D P D I Switch

B- Dry cell batteries ( 1.5 volts) 


\section{PRELIMINARY EXPERIINENTAL}

The prelimingry experimental work was divided tinto three sections, as follows:

1. The examinetion of electrodes to find those which attain equilibrium quickly, and whlch gave appreciable changes in voltage with varlations in hydrogen ion concentration. 2. The qualification of these electrodes by tests to which they worowere put in order to fully prove their stablilty and accuraoy •

8. The examinstion of simple neutralization curves and the sclection of curves of such acids and bases as could be used in the final experimental work.

The electrodes used in the preliminary experimental work were prepared as follows:

The hydrogen electrode, a dip type by Hildebrand, was platinized for three minutes in a three percent platinic chloride solution containing traces of lead acetate. The electrode was connected to a tank of hydrogen through a purification train containing potassium permanganate, alkaline pyrogallic acid, sulfuric acid and water.

The lead electrode, a strip of lead $1 \mathrm{~cm} \cdot \times 3 \mathrm{~cm} \cdot x \cdot 2 \mathrm{~cm}$ was cleaned, then plated with lead from a lead fluoborate bath ( 1 The platimam electrode was a strip of polished platinum $.8 \mathrm{~cm} . x 2 \mathrm{~cm} . x .05 \mathrm{~cm}$., welded to a platinum wire through a glass tube and connected by mercury to a copper lead. 
The quinhydrone electrode consisted of a plece of gold wire wound around the end of a glass tube, and connected to a copper lead by a short piece of welded platinum wire. It was cleaned by dipping into concentrated hydrochloric acid, was rinsed, and dipped into ammonium hydroxide. It was rinsed again and was allowed to stand for thirty minutes immersed in a saturated solution of quinhydrone in distilled water. After saturation 1 t was ready for use and was kept in distilled water.

Several saturated calomel electrodes were prepared In the usual manner and a tenth-normal calomel electrode was prepared for use In checking the values of the others. The saturated calomel electrodes were checked against each other, and with the hydrogen electrode against a buffer solution, and one was selected for use which gave the most constant voltage.

Bach electrode was combined with a saturated cabonel electrode in a cell used in a potentiometric titration of an acld with a base. Acetie acid was selected because of its relation to the lead acetate solution and potassium hydroxide was selected because of 1 ts purity. The electrode and the side arm of the saturated calomel electrode were immersed in a beaker containing 100 c.c. of conductivity water. The electromotive force of the standard cell was impressed across the potentiometer so each division of the slide wire represented a fall in potential of one millivolt. The electrodes were connected as shown in the diagram of the clroult. In using the 
hydrogen electrode, hydrogen gas was bubbled through the electrode at the rate of two bubbles per second. In using the quinhydrone electrode, crystals of quinhydrone were added to the solution unt1l 1t was saturated, only small quant1ty being necessary.

Ten cuble centimeters of tenth-normal acld were placed in the beaker and the solution was stirred thoroughly. The solution of tenth-normal base was run into the acid in small portions and after the addition of each portion the solution was again stirred. The electromotive force of the cell was measured after the addition of each portion of alkall, by adjusting the potentiometer until no deflection was observed in the gelvanometer when the tapping key was closed. Readings were obtalned over a range from acid to basic. The same titration was repeated for each electrode. The voltage readIngs obtalned were calculated to $\mathrm{pH}$ and the values of $\mathrm{pH}$ were plotted against the corresponding burette readings. The titrations were then repeated with the addition of $10 \mathrm{c.c}$. of twentfreth-normal leed acetate solution to the acld solution. This was done to determine which electrodes could be used in the presence of lead acetate solutions.

The results of these titrations were as follows: The hydrogen electrode attained equilibrlum quickly and gave a good curve in the simple titration of acetic acid and potassium hydroxide. In the presence of lead acetate, however, it gave low and variable readings, and attained equilibrium slowly. This was in accordance with the fact that lead, along with metals that stand below hydrogen in the 
electromotive force series are reduced on the electrode.

The lead electrode attained equilibrium slowly, and did not exhibit very marked changes in voltage with varlations In hydrogen ion concentration, and 1ts results did not check with the hydrogen electrode. It was also readily corroded in basis solution.

The platinum electrode acted in a similar manner to the lead electrode but was not corroded in any way.

The quinhydrone electrode attained equilibrium quickly and gave a curve that checked closely with that obtained with the hydrogen electrode. It also gave good results in the presence of lead acetate.

From these preliminary titrations $1 t$ was decided to use only the quinhydrone electrode in the final titrations, and to use the hydrogen electrode as a standard wherever possible.

In the titrations in the presence of lead acetate the use of a salt bridge was necessary to prevent the precipitation of the lead by the potassium solution from the calomel electrode. A bridge was prepared by filling a bent glass tube of six millimeter bore with a hot solution of agar-agar in saturated potassium chloride. When this cooled solid gel was formed in which the potassium chloride crystalized out. The bridge prevented contamination of the electrode by diffusion of solution into it and also served to out down any potential difference at the solution-solution junction. The connecting vessel contained saturated potassium chloride solution. 


\section{FI NAL FXXPERIMENTAL}

Titrations were carried out under careful control of conditions to eliminate as much as possible any slight sources of error. Exactiy tenth-normal solutions of acetic acid and potassium hydroxide were prepared by standardizing the base against oxal1c acid. A water bath constant to two-tenths of a degree, was set at $25^{\circ} \mathrm{O}$. and the beaker containing this solution to be titrated was placed in this water bath.

Titrations were carried out in three different media, conductivity water (pH 6.75 ), distilled water (pH $5-6$ ), and tap water ( $\mathrm{pH} 7.05$ ). The results show that any variations in the curves due to the mexinar was negligible. Since the pH of conductivity water could not be kept constant over any period of time, it was decided to use good distilled water in the t1trations.

Titrations were carried out using the quinhydrone electrode to measure the $\mathrm{pH}$ of lead acetate solutions. The method was as follows: Ten cublo centimeters of twentiethnormal lead acetate were placed in $100 \mathrm{cc}$. of distilled water and the pH of the solution was measured. Ten c.c. of tenthnormal potassium hydroxide were added in one c.c.portions and the pH of the solution was measured after the addition of each portion. To the resulting lead hydroxide tenth-normel acetic ac1d was added in one 0.0.portions unt1l a total of twenty c.c. had been added. The titration thus carried lead acetate through lead hydroxide, basic lead acetate back to normal lead acetate. 
The titration on the basic side was carried out as follows: $10 \mathrm{c.c}$. of twentleth-normal lead acetate solution were placed in 100 c.e. of distilled water and the pH of the solution was measured. $10 \mathrm{c.c}$. of tenth-normal acetic acid were added in $1 \mathrm{c.c}$. portions and the pH of the solution was measured after the addition of each portion. To the solution tenth-normal potassium hydroxide was added in 1 c.c.portions unt11 a total of $20 \mathrm{c.c}$. had been added. Th1s t1tration thus carried normal lead acetate through basis lead acetate to lead hydroxide. During these titrations motor stirrer was used to $\mathrm{mix}$ the solutions thoroughly before each measurement was made.

Tables I to VI show the data obtalned from a number of representative titrations. Values are given for c.c. of alkall and acld used, and the corresponding voltage observed. The values of $\mathrm{pH}$ were calculated from the voltage readings. The temperature for each titration is given. The acld and base were tenth-normal except where marked otherwise. The lead acetate solut1on was twentleth-normal. Curves III to VI are graphic representations of the results plotting c.c. of acld or base against pH. 


\section{TABLE I}

Titration of 1.002 tenth-normal acetic acid with .966 tenth-normal potassium hydroxide using the hydrogen electrode. . Temperature $25^{\circ} \mathrm{C}$.

\begin{tabular}{|c|c|c|c|c|}
\hline C.c.Ac1d & c.c.Base & Millivolts & $\mathrm{pH}$ & Remarks \\
\hline 0.0 & 0.0 & 549.0 & 5.12 & 100 c.c.distllled water \\
\hline \multirow[t]{20}{*}{20.0} & 0.0 & 441.0 & 3.29 & \\
\hline & 5.0 & 489.0 & 4.10 & \\
\hline & 8.0 & 506.4 & 4.40 & \\
\hline & 20.0 & 516.4 & 4.56 & \\
\hline & 12.0 & 527.5 & 4.75 & \\
\hline & 14.0 & 540.0 & 4.97 & \\
\hline & 16.0 & 556.0 & 5.24 & \\
\hline & 18.0 & 585.5 & 5.74 & \\
\hline & 18.5 & 600.0 & 5.98 & \\
\hline & 18.75 & 614.0 & 6.22 & \\
\hline & 19.08 & 665.2 & 7.08 & \\
\hline & 19.10 & 700.8 & 7.70 & \\
\hline & 19.20 & 754.4 & 8.60 & \\
\hline & 19.30 & 780.4 & 9.04 & \\
\hline & 19.50 & 811.8 & 9.57 & \\
\hline & 20.0 & 843.2 & 10.10 & \\
\hline & 21.0 & 869.4 & 10.55 & \\
\hline & 22.0 & 882.5 & 10.77 & \\
\hline & 24.0 & 897.4 & 11.02 & \\
\hline & 26.0 & 906.3 & 11.17 & \\
\hline
\end{tabular}




\section{TABLE I - CONTINUED:}

\begin{tabular}{|c|c|c|c|c|}
\hline C.e.Acid & c.c.Base & M1111volts & $\mathrm{pH}$ & Remarks : \\
\hline & 28.0 & 912.3 & 11.27 & \\
\hline & 30.0 & 917.5 & 11.36 & \\
\hline & 35.0 & 927.0 & 11.52 & \\
\hline & 40.0 & 933.0 & 11.62 & \\
\hline
\end{tabular}


Titration of 1.002 tenth-normal acetic ac1d with .966 tenthnormal potassium hydroxide using the quinhydrone electroda. Temperature $25^{\circ} \mathrm{C}$.

\begin{tabular}{|c|c|c|c|c|}
\hline c.c.Ac1d & c.c.Base & M1111volts & $\mathrm{pH}$ & Remarks \\
\hline 0.0 & 0.0 & -170.0 & 4.77 & 100 c.c.distilled water \\
\hline 10.0 & 0.0 & 251.0 & 3.40 & \\
\hline & 1.0 & 235.0 & 3.65 & \\
\hline cobseyt & 2.0 & 221.0 & 3.92 & Howay \\
\hline & 3.0 & 210.0 & 4.00 & 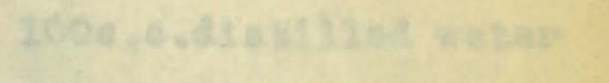 \\
\hline & 4.0 & 201.2 & 4.25 & 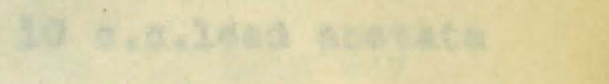 \\
\hline & 5.0 & 193.4 & 4.40 & \\
\hline & 6.0 & 185.5 & 4.50 & \\
\hline & 7.0 & 177.5 & 4.65 & \\
\hline & 8.0 & 168.5 & 4.90 & \\
\hline & 9.0 & 150.0 & 5.12 & \\
\hline & 9.5 & -132.0 & 5.44 & \\
\hline & 9.80 & +4.0 & 7.73 & \\
\hline & 9.90 & +41.0 & 8.35 & \\
\hline & & 61.6 & 8.70 & \\
\hline & 10.5 & 100.0 & 9.35 & \\
\hline & 11.0 & 118.0 & 9.65 & \\
\hline & 12.0 & 145.0 & 10.12 & \\
\hline & 13.0 & 164.0 & 10.44 & \\
\hline & 14.0 & 183.0 & 10.76 & \\
\hline & 15.0 & 204.0 & 11.08 & \\
\hline & 16.0 & 226.5 & 11.50 & \\
\hline & 17.0 & 239.5 & 11.72 & . \\
\hline & 18.0 & 254.5 & 11.97 & \\
\hline & 19.0 & 270.0 & 12.23 & \\
\hline & 20.0 & +279.0 & 12.39 & \\
\hline
\end{tabular}




\section{TABLE III}

Titration of tweitieth-normal lead acetate with tenth-normal potassium hydroxide using the quinhydrone electrode. Temperature $25^{\circ} \mathrm{C}$.

\begin{tabular}{|c|c|c|c|c|}
\hline \multirow[t]{13}{*}{ C.c.Acid } & c.c.Base & M11l1volts & $\mathrm{pH}$ & Remarks \\
\hline & 0.0 & -152.5 & 5.08 & 100c.c.d1st1lled water \\
\hline & 0.0 & 66.0 & 6.54 & 10 c.c.lead acetate \\
\hline & 1.0 & 36.0 & 7.05 & \\
\hline & 2.0 & -20.0 & 7.80 & \\
\hline & 3.0 & +8.8 & 7.80 & \\
\hline & 4.0 & 67.1 & 8.79 & \\
\hline & 5.0 & 102.0 & 9.38 & \\
\hline & 6.0 & 124.0 & 9.74 & \\
\hline & 7.0 & 144.0 & 10.08 & \\
\hline & 8.0 & 161.0 & 10.37 & \\
\hline & 9.0 & 180.0 & 20.69 & \\
\hline & 10.0 & +195.0 & 10.94 & \\
\hline
\end{tabular}




\section{TABLE IV}

Titration of twentleth-normal lead acetate w1th tenth-normal acetic acld using the quinhydrone electrode. Temperature $25^{\circ} \mathrm{C}$.

\begin{tabular}{rrrr} 
c.c.Base c.Acid & M111volts & \multicolumn{1}{c}{ RH } & Remarks \\
0.0 & -152.5 & 5.08 & 100 0.0.d1st1lled water \\
0.0 & 65.0 & 6.56 & 10 0.0.1ead acotate \\
1.0 & 131.0 & 5.43 & \\
2.0 & 150.5 & 5.13 & \\
3.0 & 164.7 & 4.89 \\
4.0 & 173.0 & 4.73 \\
5.0 & 179.0 & 4.61 \\
6.0 & 184.4 & 4.54 \\
7.0 & 188.4 & 4.46 \\
8.0 & 192.0 & 4.40 \\
9.0 & 195.0 & 4.35 \\
10.0 & -197.7 & 4.32
\end{tabular}


Titration of twentieth-normal lead acetate and tenth-normal potassium hydroxide with tenth-normal acetic acld using the quinhydrone electrode. Temperature $25^{\circ} \mathrm{C}$. c.c.Acid c.c.Base Millivolts

$\mathrm{pH}$ Remarks

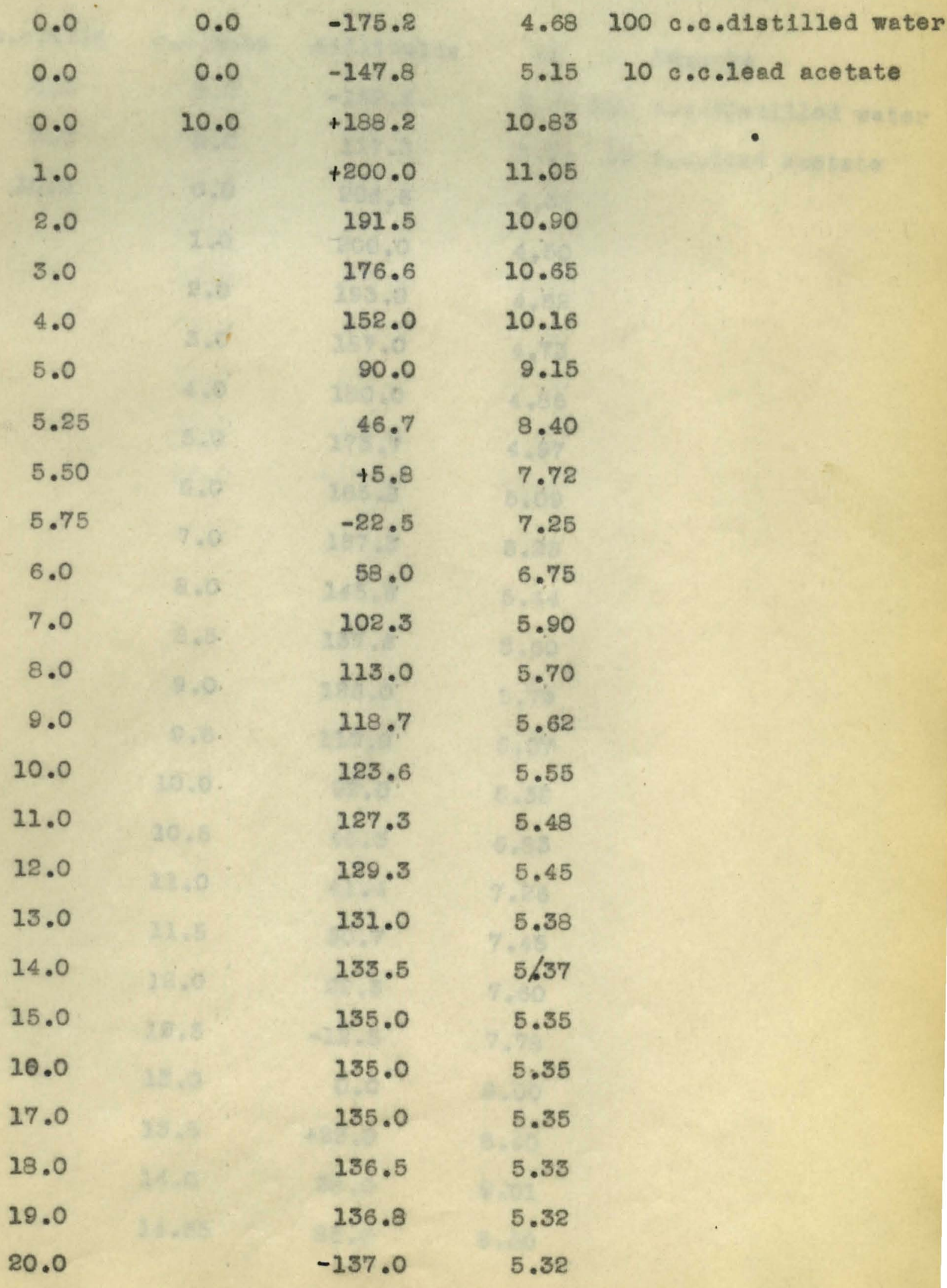


TABLE VI

Titration of twentieth-normal lead acetate and tenth-normal acet10 acid with tenth-normal potassium hydroxido using the quinhydrone electrode. Temperature $18^{\circ} \mathrm{C}$.

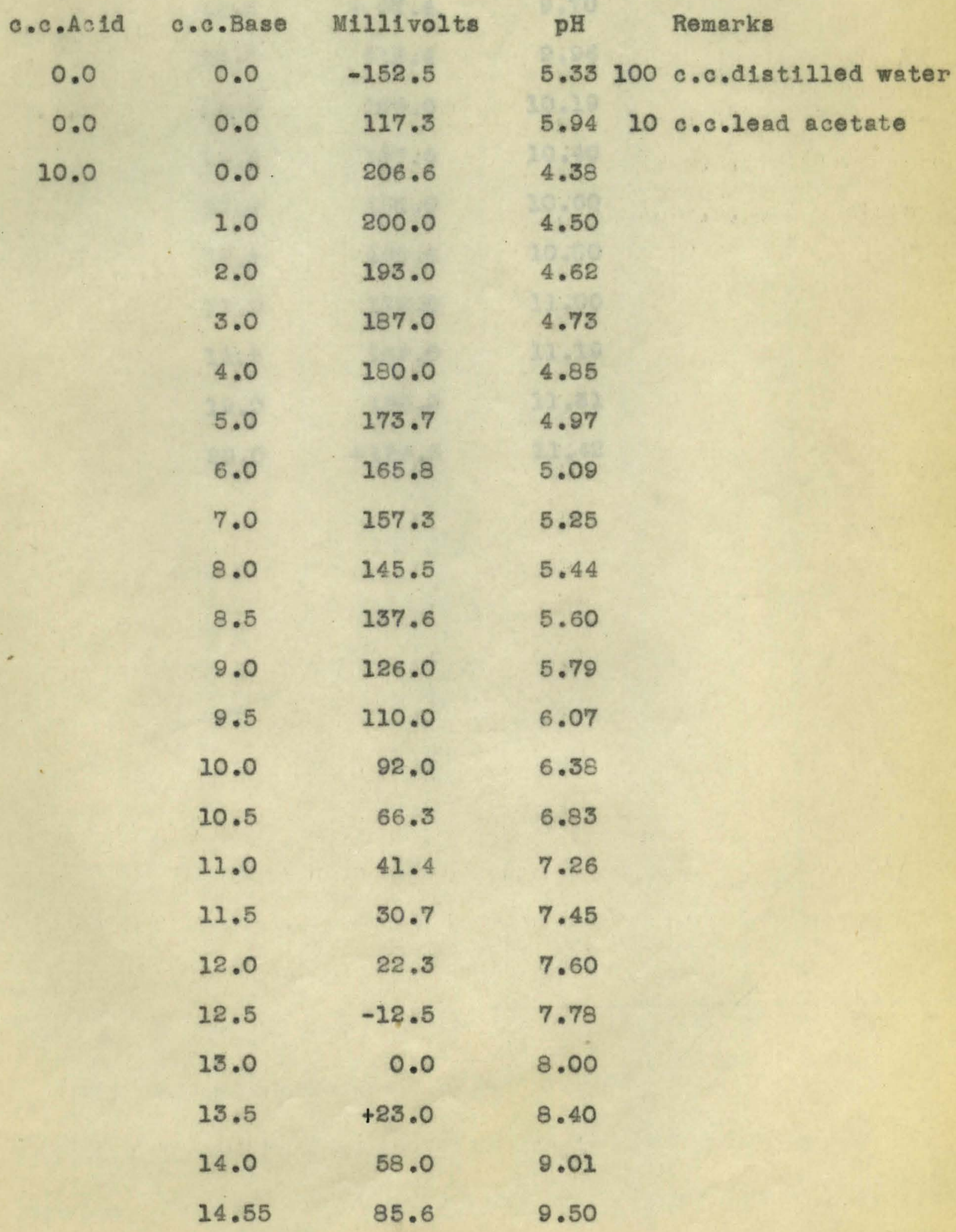




\section{TABLE VI - CONTINUED:}

$\begin{array}{cccc}\text { c. . Bcid } & \text { M111volts } & \mathrm{pH} & \text { Remarks } \\ 15.0 & +97.4 & 9.70 \\ 15.5 & 112.4 & 9.96 \\ 16.0 & 125.6 & 10.19 \\ 16.5 & 137.6 & 10.40 \\ 17.0 & 150.0 & 10.60 \\ 17.5 & 160.6 & 10.80 \\ 18.0 & 172.0 & 11.00 \\ 18.5 & 183.0 & 11.19 \\ 19.0 & 190.0 & 11.31 \\ 20.0 & +196.5 & 11.42\end{array}$


29

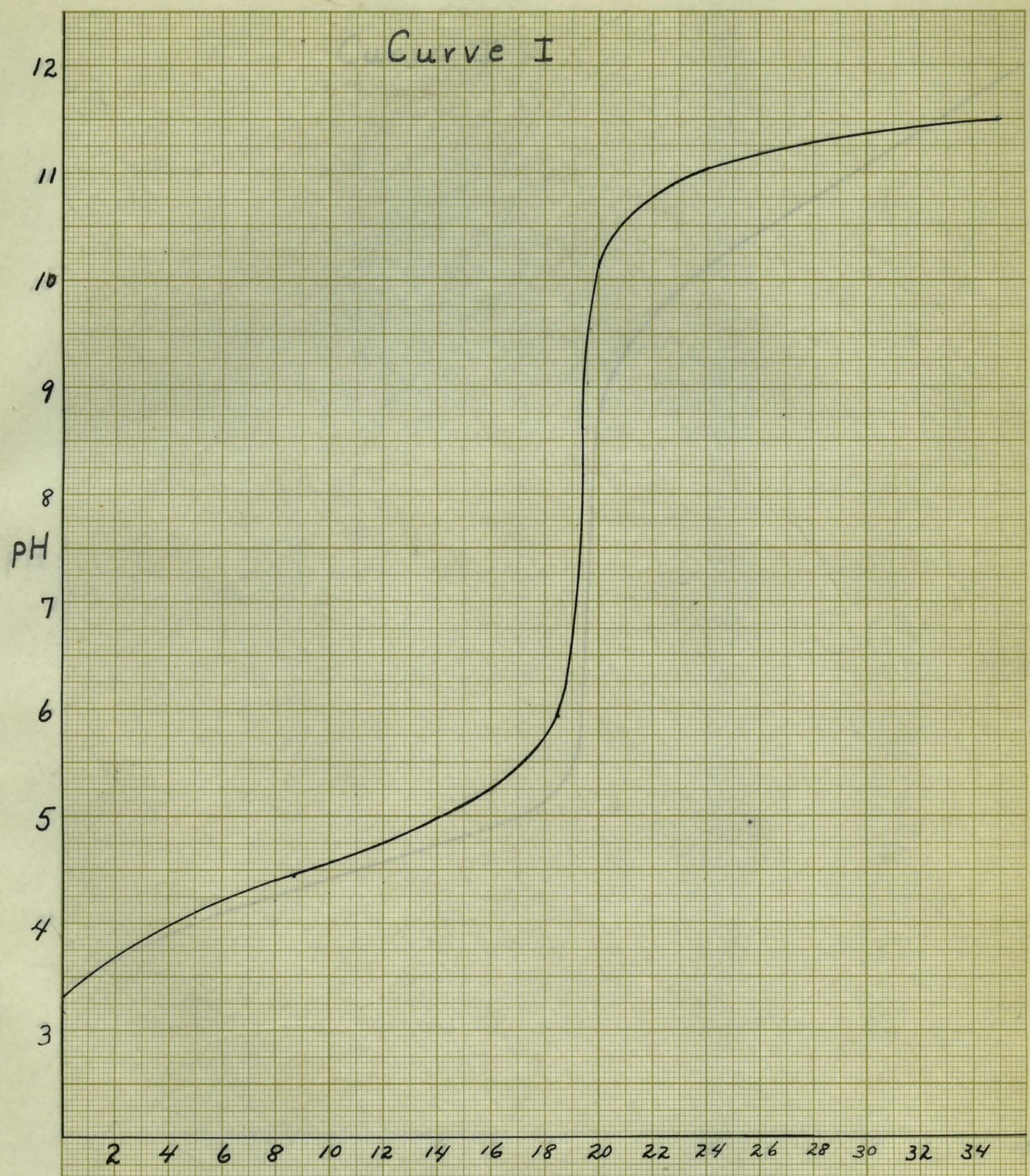

c.c. of .0966 Normal KOH added.

Titration of 20 cc. of $1002 \mathrm{~N}$. Acetic Acid with .0966 N. Potassium Hydroxide. Hydrogen Electrode. 
30

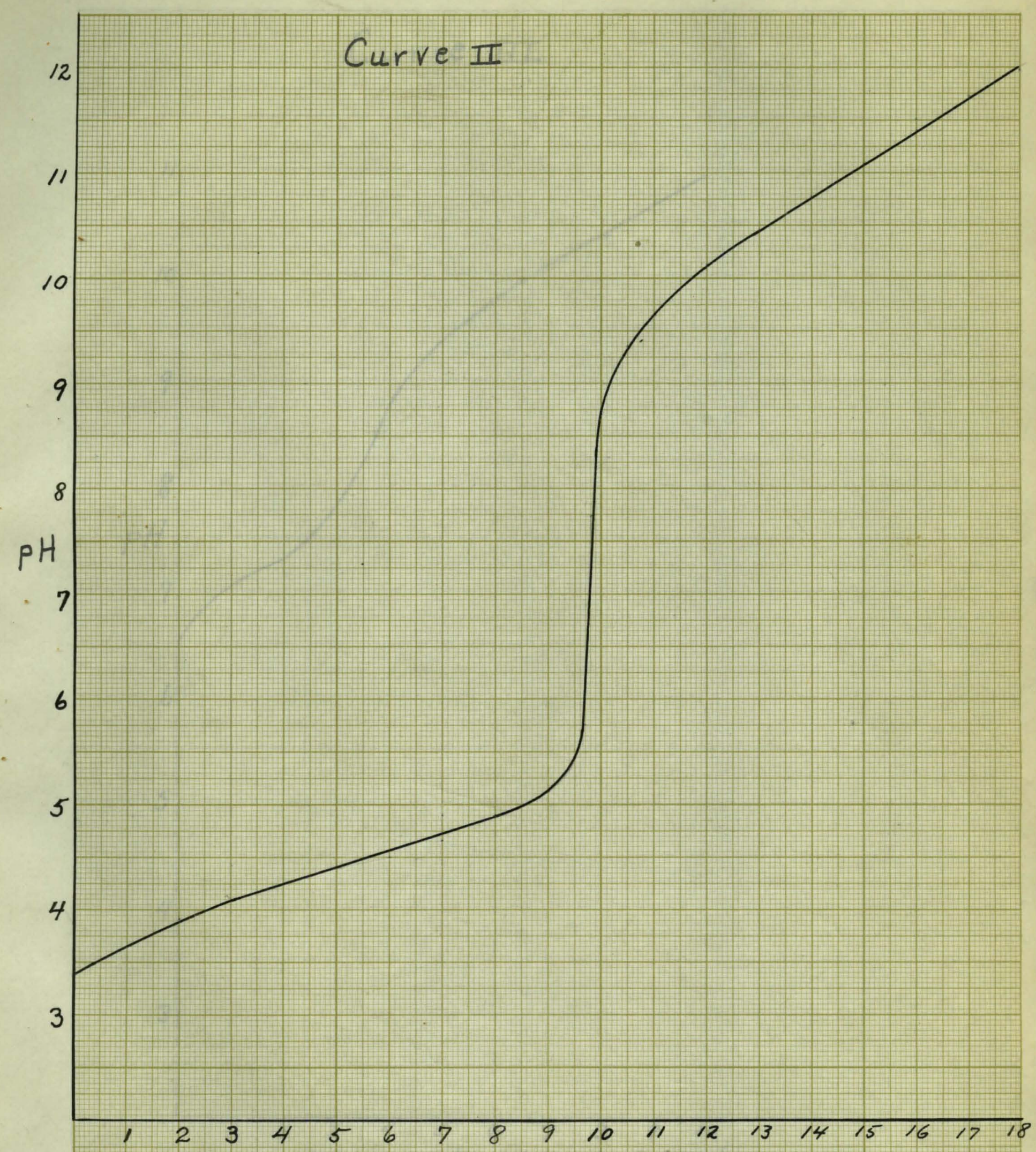

cc. of .0966 Normal KOH Added.

Titration of 10.C.C. of .1002 N. Acetic Acid with .0966 N. Potassium Hydroxide. Quinhydrone Electrode. 
31

Curve III

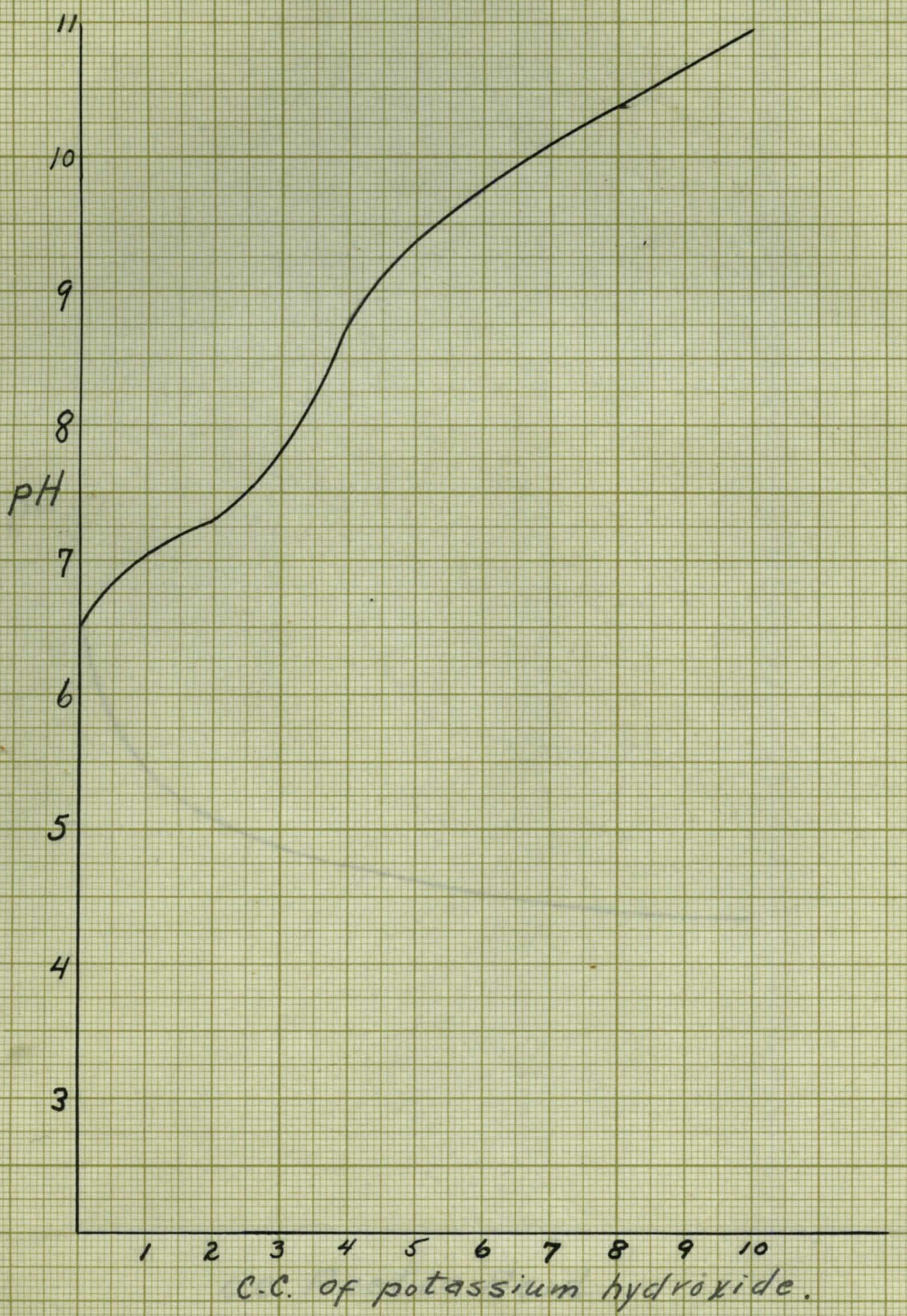

Titration of 10 aec. $\frac{\mathrm{N}}{20}$ lead ace tate with $\frac{\Lambda}{10}$ potassium hydroxide. Quinhydrone Electrode. 
32

Curve IV

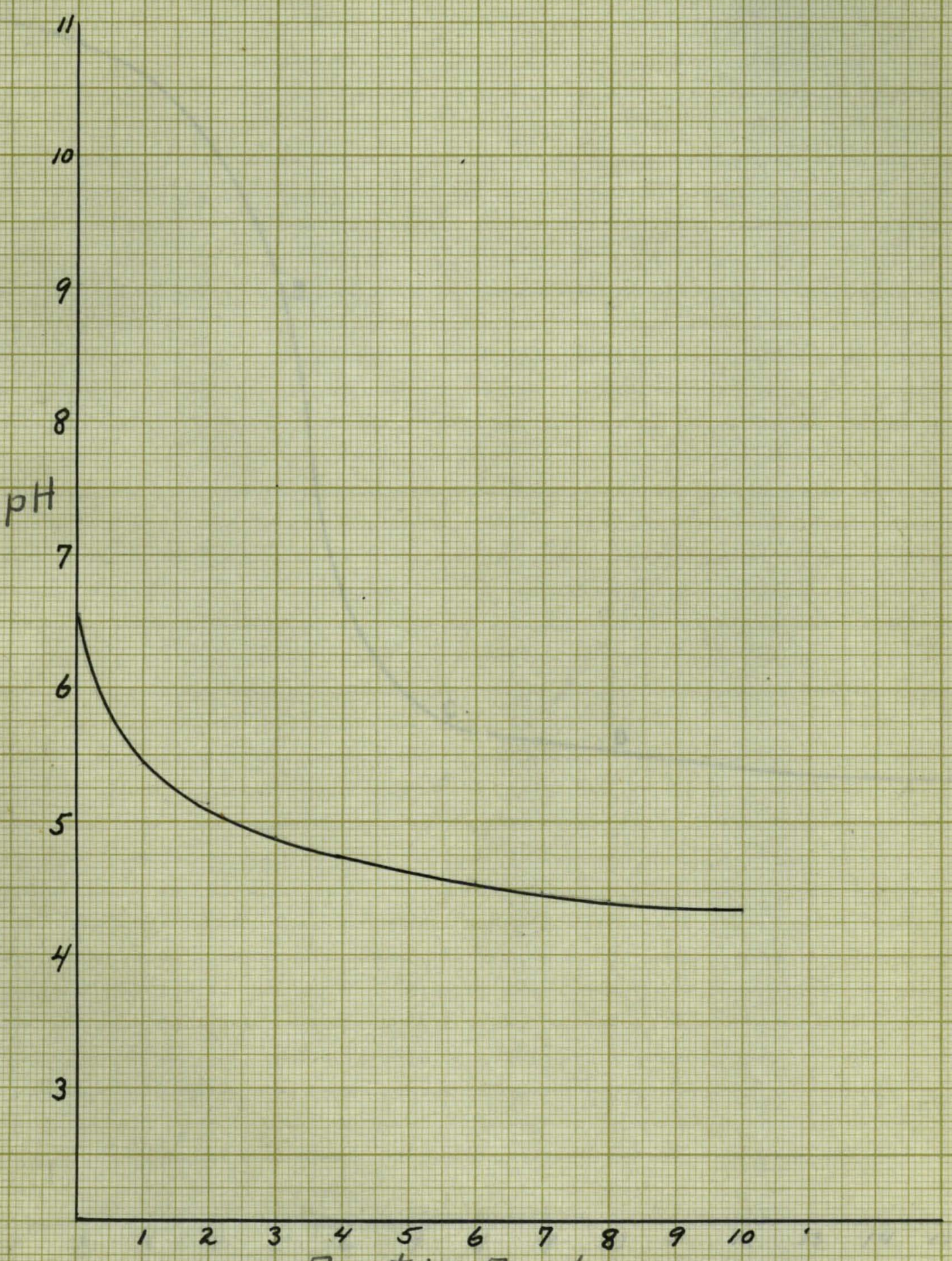

cc. Acetic Acid.

Titration of 10 cc. $\frac{N}{20}$ lead acetate with $\frac{N}{10}$ acetic acid. Quinhydrone Electrode. 


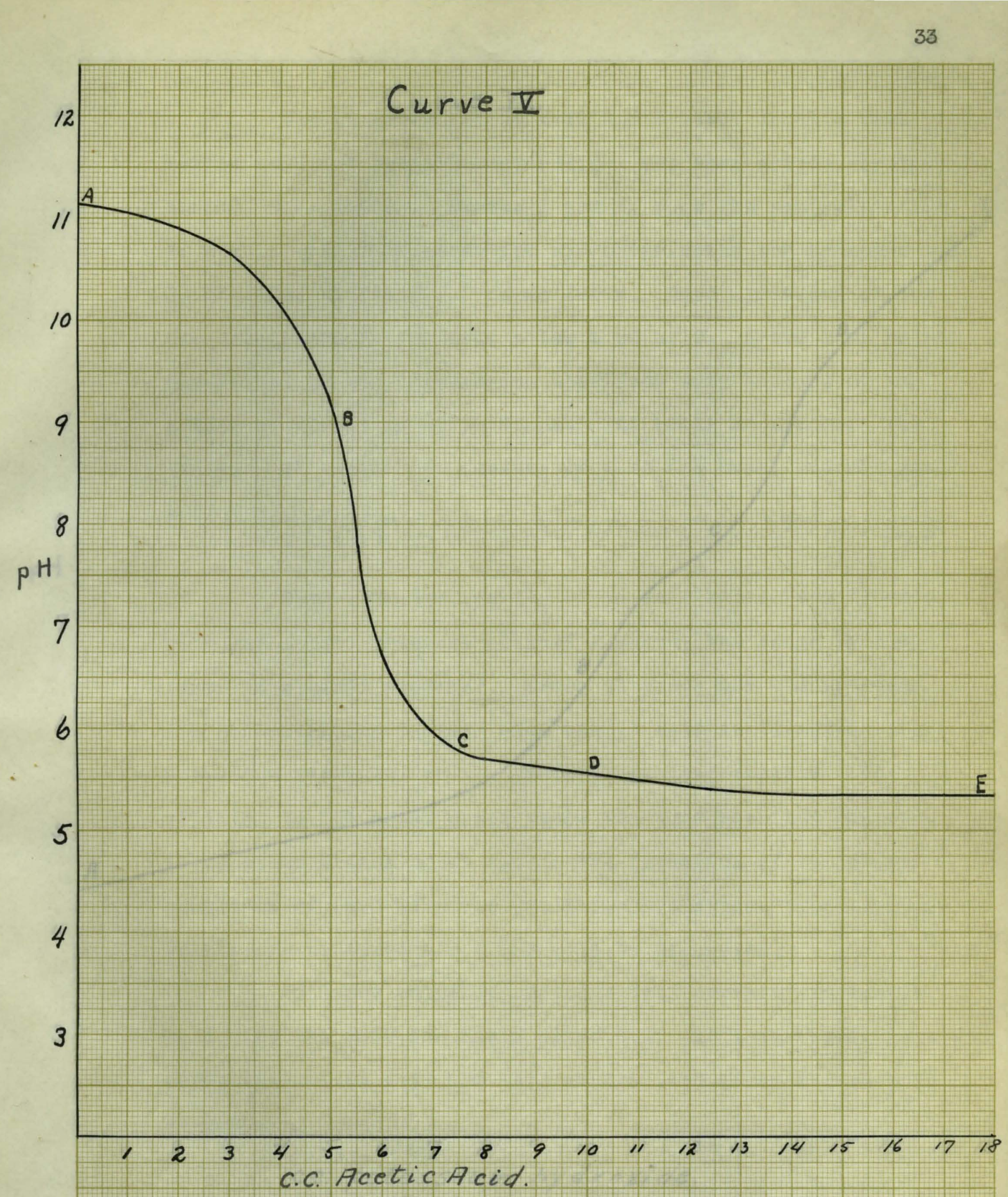

Titration of 10c.c. $\frac{N}{20}$ lead acetate and 10c.C. $\frac{N}{10}$ potassium hydroxide with $\frac{N}{10}$ acetic acid. Quinhydrone Electrode. 
34

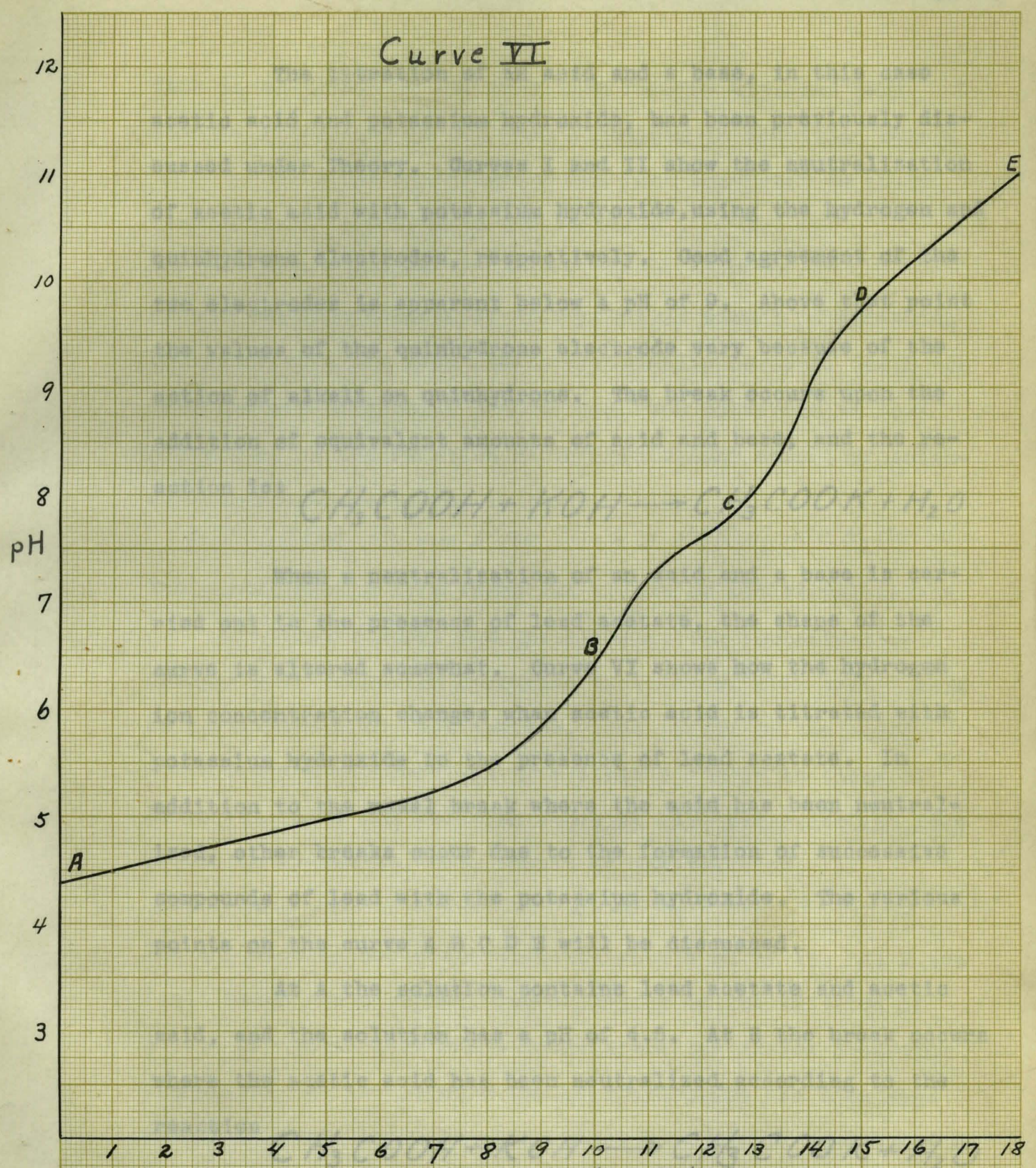

cc. potassium hydroxide.

Titration of 10c.e. $\frac{N}{20}$ lead acetate and 10 ac. $\frac{N}{10}$ acetic acid with $\frac{N}{10}$ potassium hydroxide. Quinhydrone Electrode. 
The titration of an acid and a base, in this case acetic acid and potassium hydroxide, has been previously diseussed under Theory. Curves I and II show the neutralization of acetic ac1d with potassium hydroxide, using the hydrogen and quinhydrone electrodes, respectively. Good agreement of the two electrodes is apparent below a pH of 9 . Above that point the values of the quinhydrone electrode vary because of the action of alkall on quinhydrone. The break occurs upon the addition of equivalent amounts of ac1d and base, and the reaction 1s:

\section{$\mathrm{CH}_{3} \mathrm{COOH}+\mathrm{KOH} \longrightarrow \mathrm{CH}_{3} \mathrm{COOK}_{+} \mathrm{H}_{2} \mathrm{O}$}

When a neutralization of an acid and a base is carried out in the presence of lead acetate, the shape of the eurve is altered somewhat. Gurve VI shows how the hydrogen Ion concentration changes whan acet1c ac1d is titrated with potassium hydroxide in the presence of lead acetate. In addition to the usual break where the acld has been neutralized, other breaks occur due to the formation of successive compounds of lead with the potassium hydroxide. The various points on the curve A B C D $E$ w1ll be discussed.

At A the solution contains lead acetate and acetic acid, and the solution has $\mathrm{pH}$ of 4.5 . At $\mathrm{B}$ the break occurs where the acetic acld has been neutrallzed, according to the reaction

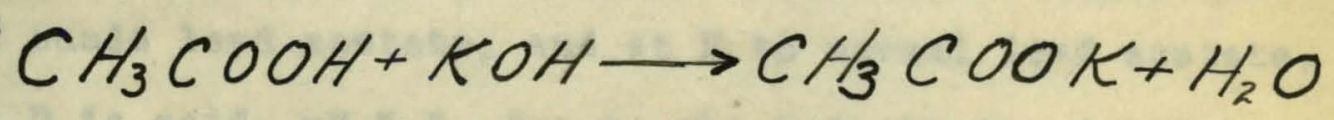

The lead acetate is unchanged. The solution has a pH of 6.3 . At this point the solution 1s slightly acid, due to the fact that lead acetate solutions hydrolyze and give an ac1d reaction. 
This is confirmed by the fact that freshly prepared lead acetate gives a $p H$ of 6.5 when dissolved in distilled water. At $c$ the lead acetate has been converted to basis lead acetate according to the reaction, $2\left(\mathrm{CH}_{3} \mathrm{COO}\right)_{2} \mathrm{~Pb}+2 \mathrm{KOH} \longrightarrow\left(\mathrm{CH}_{3} \mathrm{COO}_{2} \mathrm{PH}_{2} \mathrm{~Pb}(\mathrm{OH})_{2}+2 \mathrm{CH}_{3} \mathrm{COOK}\right.$ by the reaction of half of an equivalent amount of potassium hydroxide with the lead acetate originally present. At $D$ the lead acetate originally present hos been converted to lead hydroxide, by the reaction of one equivalent amount of potasslum hydroxide according to the reaction,

$$
2\left(\mathrm{CH}_{3} \mathrm{COO}_{2} \mathrm{~Pb}+4 \mathrm{KOH} \longrightarrow 2 \mathrm{~Pb}(\mathrm{OH})_{2}+4 \mathrm{CH} \mathrm{COOK}_{3}\right.
$$

The region from $D$ to $B$ shows the effect of additional alkall. Curve V shows how the hydrogen ion concentration changes when potassium hydroxide is titrated with acet1c acid In the presence of lead acetate. The points on the curve A B C D $B$ may be explained in a similar manner to those of Gurve VI. At A the solution contains lead hydroxide and free potassium hydroxide, as a result of the reaction,

$$
\left.2\left(\mathrm{CH}_{3} \mathrm{COO}\right)_{2} \mathrm{~Pb}+8 \mathrm{KOH} \longrightarrow 2 \mathrm{~Pb}_{2} \mathrm{OH}\right)_{2}+4 \mathrm{HOH}_{4} \mathrm{HCH}_{3} \mathrm{COOH}
$$

The solution is decidedly alkaline with a pH of 11 . At B the first break has occurred, corresponding to the addition of 5 c.e. of acet1c acid which neutralized the excess potassium hydroxide. At the point $\mathrm{C}$ the lead hydroxide has been converted to basis lead acetate, and at $D$ to normal lead acetate. The point $D$ is acid, pH 5.5, due to the hydrolgsis of the lead acetate. From $D$ to $\mathrm{E}$ the addition of more acetic acid has very little effect on the hydrogen Ion concentration of the solution. Buffer action has taken place, due to the 
presence of potassium acetate, and although the point $D$ is not at a pH of 7 , it indicates the true neutralization point or lead acetate, and gives a method of determining the neutralization point of basic lead acetate solutions with acetic ac1d.

Curves III and IV show how the quinhydrone electrode can be utllized in determining the hydrogen Ion concentration of lead acetate solutions to be used in the precipitation of chrome yellow pigments. Gurve III shows the addition of potassium hydroxide to lead acetate and shows the basic resction. Curve IV shows the addition of acetic acid to lead acetate, and shows the acid reaction. similar ourves can be prepared from any lead acetate solution, and show that from a $\mathrm{pH}$ of 4 to a $\mathrm{pH}$ of 10 , the quinhydrone electrode may be used to measure the $\mathrm{pH}$. The hydrogen ion concentration may be controlled on the acid side by the addition of acetic acid, and on the basic side by the addition of potassium hydroxide. As an introduction into the application of the measurement of hydrogen Ion concentration in lead acetate solutions, an experiment was performed to determine whether the hydrogen Ion concentration affected the oolor of lead chromate. Many factors have been found to affect the color of precipitated lead chromate. The effects of temperature, concentration, and agitation have been studied by Wagner and Keldel (11).

By keeping all these factors constant, and varying only the hydrogen 1 on concentration of the lead acetate solutions used, positive results were obtained. Solutions 
of lead acetate and sodium dichromate of strength 2 normal were prepared. Samples of $154.7 \mathrm{c.c}$. of lead acetate solution were taken and each was corrected to a definite pH by the addition of potassium hydroxide or acetic acid. The solutions had a pH of $4,5,6,7$, and 8 , respectively. They were all diluted to $309.5 \mathrm{c.c}$, which made them normal solutions. The pH of the sodium dichromate could not be measured by use of the quinhydrone electrode, but was nearly neutral. Samples of 77.4 c.c. were diluted to $386.9 \mathrm{c.c} .$, which made them .4 normal solutions. The lead acetate solutions were then added to the dichromate solutions, all at the same temperature, $23^{\circ} \mathrm{C} ., 211$ at the same rate of addition, 1 c.c. per second, and all at the same rate of agitation. The color of the resulting precipitates was observed, before and after washing and filtering.

The results showed the color of the precipitated lead chromate to vary with the $\mathrm{pH}$ of the lead acetate solution used as follows:

$$
\begin{array}{ll}
\mathrm{pH} 4 \text { - Light Yellow } & \mathrm{pH} 7 \text { - Orange Yellow } \\
\mathrm{pH} 5 \text { - Medium Yellow } & \mathrm{pH} 8 \text { - Orange } \\
\mathrm{pH} 6 \text { - Medium Yellow } &
\end{array}
$$

The color of the precipitated lead chromate thus varies from light yellow to Orange over a range of $\mathrm{pH} 4$ to $\mathrm{pH} 8$. This experiment showed that the hydrogen Ion concentration does affect the color of preclpitated lead chromate. It is hoped that this paper will lead to a further study of the effect of hydrogen Ion concentration, using the quinhydrone electrode to measure the $\mathrm{pH}$ of the lead acetate solutions. 


\section{CONGLUSIONS.}

1 - The hydrogen electrode cannot be used for the measurement of hydrogen ion concentration in lead acetate solutions.

2 - The quinhydrone electrode can be used to determine the neutralization point in the titration of acotic acid-with potassium hydroxide in the presence of lead acetate.

3- The quinhydrone eleotrode ean be used to measure the hydrogen Ion eoncentration of lead acetate solutions accurately over a range of pH from 4 to 10.

4 - The hydrogen 1 on concentration of the lead acetate solutions used is an important factor in the precipitation of lead chromates. With the other factors, temperature, concentration, and agitation constant, the color of the pigment varies with the hydrogen ion concentration of the lead acetate solution used.

5 - The quinhydrone electrode can be used for measuring the hydrogen ion concentration of lead acetate solutions in controlling the oolor of lead chromate precipitates. 


\section{BIBLIOGRAPHY.}

(1) F. Bergh, Apoth. Ze1tung. 24, 291.

(2) F. Bergh, " n 24, 291

(3) F. Bergh, " " 24, 291.

(4) I. M. Kolthoff, Pharm. Weekblad. 57, 252-65 (1920).

(5) H. Langecker, Blochem. Z. 122, 34-8 (1921).

(6) Sorensen, Blochem. Ze1t., 21, 131 (1909).

(7) B111mann, Ann. Ohim. Phys, 15, 109 (1921); 16, 321 (1921).

(8) Kohlrausch and Heydwelller, Ann. der Phys.(4),28,512 (1909).

(9) Böttger, Ze1t. Phys. Chem., 24, 253 (1897).

(10) Blum and Hogaboom. Principals of Blectroplating and Electroforming, p. 283.

(11) Wegner and Ke1de1, Farben Ztg. 31, No. 28, 1567-73 (1926).

\section{Books Consulted Were:}

(1) Outlines of Theoretical Chemiatry - detman.

(2) Electro Chem1stry - Cre1ghton and Fink.

(3) Treatise on Physical Chemistry - Taylor.

(4) Determination of Hydrogen Ions - Clark.

(5) Potentiometric T1trations - Kolthoff and Furman. 


\section{A CKNOWLEDGNENT.}

The author wishes to express his appreciation of the ald of Professor R. C. Frnst, who directed this research. He is indebted to the Kentucky Color and Chemical Company, which supplied materials, and to Mr. Andrew Snyder, of that company, for his kind assistance. He also wishes to thank the 011, Paint amd Varnish Club of Loulsville, whose fellowship made possible this research. 
AUTOBIOGRAPHY.

The author, Mile Pragoff, Jr., was born at Louisvilie, Kentucky, November 11, 1907, He recelved his ligh school education at Loulsville Male High School. He received his under graduate education at the University of Louisville, from which he was graduated, with the degree of Bachelor of Science in Chemistry, in 1927. He received the 011. Paint and Varnish Glub Fellowship for research in paints. He held a teaching fellowship in the Department of Chemistry of the University of Loulsville from 1928 to 1929. During that time he d1d graduate work at the University and received the degree of Mester of Sclence in 1929. 